\title{
Bad Study Habits of EFL Learners as Indicators of their Poor Performance: A Case of the University of Bisha
}

\author{
Al-Maqtri Mahmoud Ahmad
}

English Department, College of Sciences and Arts, University of Bisha, An-Namas, KSA

Department of English, Faculty of Arts, Ibb University, Ibb, Yemen

Corresponding Author: Al-Maqtri Mahmoud Ahmad, E-mail: mmaktri@yahoo.com

\section{ARTICLE INFO}

\section{Article history}

Received: November 08, 2017

Accepted: January 17, 2018

Published: March 01, 2018

Volume: 7 Issue: 2

Advance access: February 2018

Conflicts of interest: None

Funding: None

\begin{abstract}
The objective of this study was to identify the study habits of the college students of English, and examine their role on the their performance as assessed by the instructors. The study was intended to be a preliminary and exploratory one and to be followed by a more at a larger scale study. The participants were 150 students distributed between males $(60 \%)$ and females $(40 \%)$. They were selected purposefully representing the different academic years from the Departments of English, Colleges of Sciences and Arts, University of Bisha, An-namas, KAS. Three different tools were used to collect the data: a self-prepared 19-item survey questionnaire, informal observations, and informal meetings with the instructors of the intended groups. The percentile and frequency techniques were used to analyze the collected data. The results showed that the majority of the students, boys in particular, devoted less time to their study, revised less frequently, never took notes, did not plan their study time, and study mainly to take examinations or please parents. They studied alone in their rooms and rarely study at library. All this corresponded with the instructors' assessment that the participants' performance was below the expectations. Though this was true of both genders, females, however, did better than males in many of these respects. Their study habits were less negative; they were more motivated and therefore their performance was reported to be better than those of the males. The study concluded with some recommendations and suggestions for future actions.
\end{abstract}

Key words: EFL, Indicator, Habit, Learner, Performance, Study

\section{INTRODUCTION}

The link between study habits and academic achievement has been going on for many years (Franklin, 2017). Credé, and Kuncel found that traditional tests were found to rival study habits as predictors of academic performance (2008). This shows the role of study habits in academic performance. We have observed this link between study habits and performance with our students; it was also there when we were students. The students who, for example, plan their study time, take notes, organize themselves, take active roles in class room and so on are usually better performers and good achievers. On the contrary, those who come to class late, do not study regularly, do not take notes, do not plan study time, do not take active part in classroom are usually underachievers. Good study habits, therefore are prerequisite for effective academic performance and vice versa. This study was trying to examine the role the study habits of students of English in the Colleges of Sciences and Arts, affiliated to University of Bisha, KAS, and compare these habits with their academic performance. By examining these habits we hoped to find out if they were indicators of the students' performance. Low performance in English, therefore, is taken for granted. The study aimed to achieve the following objectives:

1) to identify the study habits of the study groups, 2) to determine the relationship between the study habits of the participants and their performance, 3 ) to find out the differences between male and female students in their study habits,4) to draw the attention to those habits that were inappropriate and create some kind of awareness of their role in the students' performance, 5) to offer some recommendations and suggestions to help those concerned for more effective and productive study habits and therefore for better performance.

\section{Study Questions}

1. What characterizes the study habits of the targeted participants?

2. Are there differences between males and females in their study habits?

3. Is there any kind of relationship between these study habits and students' performance?

4. What are the causes for the poor study habits if any?

5. Are there any discrepancies between data obtained from instructors and those from participants? 


\section{The Significance of the Study}

This study will be helpful to the different stockholders who are involved in the English teaching/learning process: students, teachers, parents, educators, course designers and policy makers. The students will be the first to benefit from the outcomes of this study. It is hoped that their attention will be drawn to the different kinds of study habits and to those habits they have to avoid and those that they can adopt to support them to do well in their study. The study will be helpful to teachers in that they can train the students and guide them to follow the positive habits and avoid the poor ones. Parents, in turn, will be awaken to the study habits and behaviors of their children and keep an eye on them and help them stay away from the unproductive habits. As for other parties like educators, course designers and policy makers all will benefit from the implications offered in adopting, adapting and implementing the teaching learning process and materials to accommodate the individual differences of the learners in the area of the study habits.

\section{Operational Definitions of Terms}

\section{Study Habits}

Study habits here refer to those actions performed by the students to acquire and learn English inside and outside the classroom. Such habits include study time, planning, scheduling, note taking, note checking, reviewing the material, asking questions, self-testing, when, where, and with whom to study...etc.

\section{Performance}

The term 'Performance' in this study refers to the students' actions and processes in understanding and using English for purposeful communication inside and outside the classroom and as represented in their achievement of tasks and tests and other classroom performance.

\section{LITERATURE REVIEW}

The first attempt to examine study habits was by Wrenn with his Study-Habits Inventory, followed by the Student Skills Inventory by Locke, (as cited in Gurung, Weidert, \& Jeske, 2010). Other attempts on this area were reported. Recently, one can find many attempts that focused on the study habits and behaviors. But as Gurung (2010) indicated that none of these attempts succeeded to offer some advice to students on how to study well.

\section{What are Study habits?}

Study habits are those habitual actions through which students learn their subject matter (Thiyagu, 2013). People perform these habits automatically and without thinking (Neal, Wood, \& Quinn, 2006).

These study habits are also defined as "behaviors serving to acquire, organize, synthesize, evaluate, remember, and use information" (Crede, \& Kuncel, 2008; Gettinger \&Seibert, 2002, as cited in Gurung et al., 2010, p.1)
Study habits are mainly external factors that facilitate the study process such as sound study routines that include how often a student engages in studying sessions, reviewing the material, self-evaluating, rehearsing, explaining the material, and studying in a conducive environment (Credé, as cited in Cerna \& Pavliushchenko, 2015).

Grede (as cited in Gurung, \& McCann, 2011) sees that study habits refer to the study behaviors of the learners, functioning to acquire, organize, synthesize, evaluate, remember and use information. Such behaviors include time management, goal setting, selecting what, how and where and with whom to study. They also include scheduling, taking notes, individual and group studying, self-testing reading, and other classroom-related actions. This is the meaning that we adopted in our study.

Some researchers (Gurung, \& McCann, 2011) divided these study behaviors into four main groups. These were repetition-based (repeating a word/expression out aloud), cognitive-based (concentrating on what lecturers say), procedural (time management) and metacognitive (planning and scheduling).

In our paper, the term 'study habits' mainly refers to the metacognitive habits like planning scheduling, organizing, revising, note taking and the like. It focuses on studying habits inside and outside classroom.

\section{Why Study Habits?}

Examining the study habits can serve as diagnostic tools to help instructors identify students in need of additional help and can also provide better awareness of the students' strengths and weakness and any other means to improve their learning (Gurung \& McCann, 2011). Study behaviors, the metacognitive ones, in particular are the best and strongest predictors of examination scores (Gurung et al., 2010).

A number of studies as shown in the reviews by Entwistle \& McCune, 2004; Crede \& Kuncel, 2008; Gurung \& Schwartz, 2011; Hattie, 2009 tried to identify and classify the study techniques that were useful. All the reviews cited showed that study attitudes/habits/behaviors are related to students' academic performance. This is in agreement with the intent of our study. However, in these attempts, it was not easy to identify which specific strategy was the best one (Gurung \& McCann, 2011).

Benford \& Gess-Newsome (2006) indicated that understanding the factors that influenced students' perseverance and satisfaction were important in their success in college. According to them, this understanding might lead to diminish those factors that affected their study habits and attitudes.

In a study aimed to identify the role of motivation and incentives in education and future career of oversea students it was suggested to turn to study habits instead of learning styles as the former can be better indicators of the students' academic performance and future orientations (West \& Sadoski, 2011).

However, the findings of the studies carried out to identify the best techniques or study habits were conflicting and ambiguous. And therefore, it was difficult to give good advice to students to follow certain techniques to perform better (Gurung et al., 2010). 


\section{Study Habits and Saudi Students}

There are indicators that most Saudi students have poor study habits. We have observed this phenomenon in different educational institutions and with different types of college students, boys in particular. Atieh (1997, p. 43) confirmed the case of poor study habits among Saudi students. The issue of poor study habits came third of the most determinant obstacles mentioned by the author. About $65 \%$ of the respondents (students) in his study opted for this response that poor study habits were one major obstacle facing students in Saudi Arabia. Though Atieh's study was not concerned with students of English, yet it gave indications that the problem was common among Saudi college students.

In another relevant study in the Saudi context with participants from Najran University (in Saudi Arabia), the author Chokri (2013) attributed academic performance to a group of interrelated factors and mentioned that the study habits factor was one of the these factors.

Some authors like Cerna and Pavliushchenoko (2015) tried to link poor study habits to the cultural differences. They differentiated between students coming from high-context cultures (collectivistic) and students who came from low context cultures (individualist). Unlike students who come from low context culture, those who came from high-context cultures were usually low-performers and their study habits were generally negative ones. High-context cultures include middle eastern countries beside others which means Saudi Arabia is included. The conclusion that high/low context cultures are responsible for bad study habits and the low performance, however does not seem to hold ground. Rather these poor study habits are due to some other social and economic factors which are time and place-specific. They also depend on the students themselves. We can classify all Arab countries as high-context ones, some of these countries give high values to learning while other do not. Moreover, within each of these countries, there are very good learners who may perform very well in different language learning contexts. Furthermore, our contact with Saudi students shows that they are as intelligent as any other students in other Arab countries. Their problem is that they are not exerting enough effort to learn due to lacking motivation.

\section{Study Habits and Performance}

It would be expected that students who possess good study habits in general are better performers than are those with poor study habits. Resan, Mecann and Terenzini (as cited in Nonis, Philhours \& Hudson, 2006) found that study attitudes, habits, and behaviors were related to academic performance. We would agree with this conclusion as we have observed this with our students in everyday classroom behaviors. Students' behaviors such as not attending classes, coming late to class or not taking notes and so on, all reflected the students' overall performance. Students who frequently came late to class were usually doing bad. Similarly, students who did not bring their note books to classroom or did not take notes were not doing well.
Some individual habits proved to have positive effects. For example, group learning activities can result in an increase in students' deep learning approach, which has been known to improve analytical thinking (Coffield, Moseley, Hall, \& Ecclestone, 2004). Williams and Worth (as cited in Cerna and Pav, 2015) concluded that attendance and note-taking predicted performance. We agree with this; for example, our students did not take notes and their performance was poor. Of course, this cannot be a one-to-one cause-effect relationship. There could be other causes for the bad performance as indicated by Lawson (2009) that low performance might not necessarily be related directly to study habits. It could be caused by other related socioeconomic factors like the low level of educated parents and so on.

However, available empirical research has shown that there exists different mixed findings of the relationship between study time and study habits and college student performance and achievement. The results have been either positive, negative or no relationship at all (see Andrade 2006; Krohn, \& O'Conner, 2005). Nonis and Hudson's also studied this relationship, and results showed that some study habits had a positive direct relationship on student performance but others had a negative direct relationship (2010).

There are other studies that revealed conflicting results about the relationship between study habits and performance. For example, Schuman, Walsh, Olson and Etheridge (1985) examined some study habits like group studying, cramming, degree of note-taking, reviewing of past exams, and going over readings twice, but they concluded that none of these variables have been found to have a direct effect on grades. On the other hand, positive results were found when some combination of study behaviors such as attendance, homework turned in, and use of study guide, prior preparation for the class, participating in class, and coming to class on time (Gracia, Shaftel, \&Wooten, as cited in Cerna \& Pav, 2015).

Gurung et al., (2010) carried out a study to assess 125 introductory psychology students' use of different study techniques and correlated their responses with their exam scores. They found study habits like attendance, study guide use, using practice exams, and using class material to explain problems were positively correlated with exam scores. Some other habits or techniques were negatively correlated with exam scores. Scores on tradition study habit and attitude inventories were said to be the most predictive of performance. However, some studies revealed that the study habits were not a powerful predictor of students' academic performance(Credé, \& Kuncel, 2008).

If study habits can predict performance as some studies have revealed, the reverse can also be true as observed by Rossi-Le (as cited in Oxford \& Burry-Stock, 1995) who found that for 147 adult ESL students in the Midwestern and the Northeastern parts of the US, language proficiency level (on a standardized test) predicted strategy use in multiple regression analyses. More proficient ESL students used self-management strategies (study habits in our case) like planning and evaluating $(\mathrm{p}<.006)$ and formal practice $(\mathrm{p}<.02)$ significantly more often than less proficient ESL students. 


\section{Study Habits and Motivation}

Earlier we indicated that study habits were not the only factor that affects performance. There is some evidence both theoretical and empirical that performance is a multifaceted function. It is not merely the amount of time devoted to study or the techniques of taking notes and managing one's study. Academic performance can be influenced by more qualitative variables, such as of ability, attitude and most important of all motivation (Chan, Schmitt, Sacco \& DeShon, 1998).

Motivation, namely internal motivation, was found to encourage positive study habits (Simons, Dewitte, \& Lens, 2004). Stoynoff (as cited in Andrade, 2006) found that motivation, among other variables, was related to achievement which was, of course, related to study habits and behaviors. Different types of motivation played different roles in the study habits and achievements. Comparisons between learners who were internally motivated and those who were externally motivated, showed that the former had more interest, confidence, excitement, persistence, better performance, and showed a better conceptual understanding of the material relative to the second group (Deci \&Ryan; Grolnick \& Ryan; Grolnick, Ryan, \& Deci; Hayamizu; Ryan \& Connell; Vallerand \& Bissonnette; Yamauchi \& Tanaka as cited in Simons etal., 2004, p.4).

Mohammad and Hazarika (2016), with reference to the Saudi context, stated that lack of motivation is one of the most important factors for the poor performance of Arab learners in writing assignments. However, this lack of motivation is not limited to writing or any of the four major skills but rather to learning English and may be to the learning process as a whole. Though some researchers tried to link these problems in language skills to language interference of the mother tongue (Khan, 2011; AlMurshidi, 2014), we attribute this rather to lack of motivation to learn and to bad study habits.

As we know there are different types of motivation most commonly known as internal motivation and external motivation. Relevant studies reported that "when internally motivated, students are more task oriented, more excited about the course, persist more, use more deep level learning strategies, and perform better. When externally regulated, on the other hand, students adopt more approach and avoidance ego goals, study less regularly, show less excitement, persist less, use more surface level strategies and perform worse." (Simon et al., 2004, p. 14). We can say that our students were not internally motivated as they exhibited those aspects of learners under this category.

\section{METHOD}

\section{The Context of the Study}

The main data collection tool was a questionnaire. The questionnaire was first given to six EFL instructors in both boy and girl colleges to ensure the validity of the survey. All of these instructors were all assistant professors. Their feedback was useful for modifying some items. The questionnaire was prepared in English, but after the modification, it was translated into Arabic so that participants could understand the meaning of the items due to low proficiency in English. Then the survey was piloted to 40 male students. The piloted subjects faced no difficulties in understanding the items. Correspondence between the responses of the pilot study and the final survey was found to be high.

\section{Participants}

One hundred and fifty full-time undergraduate students $90(60 \%)$ males and $60(40 \%)$ females) participated in this study. They were selected from the Departments of English in the two colleges of Sciences of Arts affiliated to the University of Bisha in An-Namas town, KSA. They were freshmen (28\%) sophomores (12.7\%) juniors (27.3\%) and seniors (32\%). Participation was voluntarily.

\section{Instruments}

1. A questionnaire. The questionnaire was a self-prepared and non-standardized one. The purpose of the questionnaire was to identify the study groups' study habits. It consisted of two sections: a demographic one which asked for the kind of gender of the participant, and the level or the academic year. The term 'level' here means one of the two divisions of the academic year in which each year is divided into two semesters. Each semester is called 'level'. The second section of the questionnaire consisted of 19-item multiple response survey. Most of the items were likert-type scales with most of them four alternatives (e.g. always, often, sometimes and never). The 19 items were later reduced to 14 items for the sake of brevity and because five items were not adding much to the required data. The items were about the different study habits of the target groups. The list of items was developed as a result of a thorough review of the relevant literature in a way that suits the context of our study and the target groups.

2. Informal meetings. The second tool for the data collection was informal meetings with instructors from both boys' and girls' colleges; These meetings centered around the major study habits of the students such as if the students attended regularly, if they used to bring notebooks and pens to class, if they took notes and if they participated in classroom activities, if they asked their instructors clarification questions...etc. See Table 1 for more detail.

3. Informal observations. The informal observations were conducted by the instructor/researcher to observe observable behavior and study habits (see Oxford, \& Burry-Stock, 1995). These were based on the different types of student's actions and behaviors in and out of classroom. See Table 1 for detail. All the data obtained from the informal meetings and observations were meant to supplement the data gained from the survey questionnaire.

\section{The Procedures}

The 19-item survey questionnaire was administered to the 150 participants of both genders. The participants were 
Table 1. Notes from observations and meetings

\begin{tabular}{|c|c|c|}
\hline Informal observations (Boys) & Informal meetings (Boys) & Informal meetings (Girls) \\
\hline 1. Students do not study outside classroom & Students do not study outside classroom & Some girls study outside classroom \\
\hline 2. Students frequently come late to class & Students usually come late to class & Girls sometimes come late \\
\hline 3. Some sleep in class & Some sleep during classes & Some sleep during classes \\
\hline 4. Reluctant to have classes & Reluctant to take classes & Happy not to have classes \\
\hline 5. Students are not regular & Many are not regular & Some girls are not regular \\
\hline 6. They do not read before lectures & They not read before lectures & They do not read before lectures \\
\hline 7. Few students take notes & Students do not take notes & Some take notes \\
\hline 8. They do not bring books/note books/pens & They do not bring books/note books/pens & $\begin{array}{l}\text { Some bring notes and other } \\
\text { stationery }\end{array}$ \\
\hline 9. Most do not participate & Only few participate & Some girls participate \\
\hline 10. Many try to cheat in exams & Many try to cheat in exams & The majority try to cheat in exams \\
\hline $\begin{array}{l}\text { 11. Try to plagiarize and copy from each } \\
\text { other's work }\end{array}$ & $\begin{array}{l}\text { Try to plagiarize and copy from each } \\
\text { other's work }\end{array}$ & $\begin{array}{l}\text { Try to plagiarize and copy from each } \\
\text { other's work }\end{array}$ \\
\hline $\begin{array}{l}\text { 12. Never reflect, criticize or notice } \\
\text { instructors' mistakes }\end{array}$ & $\begin{array}{l}\text { Never reflect, criticize instructors or notice } \\
\text { their mistakes }\end{array}$ & $\begin{array}{l}\text { Rarely reflect, criticize or correct } \\
\text { instructors }\end{array}$ \\
\hline 13. Never add new ideas & Do not add new ideas & Sometimes add ideas \\
\hline 14. Rarely ask questions & Rarely ask questions & Sometimes ask questions \\
\hline 15. They all revise only for tests/examinations & Most revise only to take tests/examinations & $\begin{array}{l}\text { They usually revise for tests/ } \\
\text { examinations }\end{array}$ \\
\hline $\begin{array}{l}\text { 16. Good performers usually sit at the front of } \\
\text { the class }\end{array}$ & $\begin{array}{l}\text { poor performing ones usually sit at the } \\
\text { back of the class }\end{array}$ & $\begin{array}{l}\text { Poor students mostly sit at the back } \\
\text { of the classroom }\end{array}$ \\
\hline 17. Most never return tasks on time & They never return tasks on time & Many never return tasks on time \\
\hline 18. Students generally are not motivated & Students are not motivated & $\begin{array}{l}\text { Some are motivated; More girls are } \\
\text { motivated than boys }\end{array}$ \\
\hline
\end{tabular}

selected purposefully as far as the academic year was concerned and randomly regarding the individual participants within each level (academic year). Seven instructors helped distribute the questionnaire, which was administered in the normal classes. The students took approximately 7 to $10 \mathrm{~min}$ utes to complete the questionnaire. As for the informal meetings, they were taken whenever instructors met and when the issue of students' motivation was the focus of discussion. The informal observations were undertaken by the instructor/researcher along a six-year period of time.

\section{Data Analysis}

The obtained data from the survey questionnaire were tabulated according to the frequency of each response. These frequency responses were converted to percentages. It is worth noting here that this study was intended to be a preliminary and an exploratory one and would be followed by a more in-depth and at a large scale study; Therefore, sophisticated statistics were not used at this stage. More sophisticated statistical techniques will be used in the larger study which I intend to carry out in the near future.

\section{RESULTS AND RESULT DISCUSSION}

\section{Results of Observations and Meetings}

The following tables present data for the survey questions:

Question 1: How often do you revise your lectures?
As shown in Table 3 the scores show that only $1.9 \%$ of the males said they revised on a daily basis against $5 \%$ of females. Those who said they studied on weekly basis were $13.5 \%$ for boys against $19 \%$ for females. About $16.8 \%$ boys against $12.5 \%$ girls indicated they studied monthly. The majority of the males $(63 \%)$ against $54.2 \%$ for girls said they studied only to take tests. The boys who said they never studied whatsoever recorded $4.9 \%$ against $9.2 \%$ for girls.

This is consistent with our observations and with the informal meetings with instructors (Table 1) in which the male's behavior, study habits, performance, and self-expressions all indicated that most of the students did not study outside classroom; they studied mainly to take tests. However, we can see that girls were rated better than boys. More girls studied on daily basis, and fewer girls compared with boys said they never studied even to take tests. This is in agreement with our expectations and with what instructors of both genders reported that females worked and performed better than boys in the examinations.

Question 2: How many hours do you devote to study each time?

In Tables 2 and 3 about $33.9 \%$ of the boys are shown to have studied about one hour. The same was not true about girls. Only $9 \%$ of girls indicated that they studied about one hour. This means girls studied more than boys. About 43.6 $\%$ of the boys studied between two to three hours against $25 \%$ of the girls.Only $13.3 \%$ of the males said they studied between four and five hours compared with $33 \%$ of the fe- 
Table 2. Number of times of revisions

\begin{tabular}{|c|c|c|c|c|c|c|c|c|c|c|}
\hline \multirow[t]{3}{*}{ Question No. 1} & \multicolumn{8}{|c|}{ Academic year } & \multicolumn{2}{|c|}{ Total in percentages } \\
\hline & \multicolumn{2}{|c|}{ Year 1} & \multicolumn{2}{|c|}{ Year 2} & \multicolumn{2}{|c|}{ Year 3} & \multicolumn{2}{|c|}{ Year 4} & & \\
\hline & $\mathbf{M}$ & $\mathbf{F}$ & $\mathbf{M}$ & $\mathbf{F}$ & $\mathbf{M}$ & $\mathbf{F}$ & $\mathbf{M}$ & $\mathbf{F}$ & $\mathbf{M}$ & $\mathbf{F}$ \\
\hline Daily & 4.5 & 5 & --- & --- & --- & 15 & 3.1 & --- & 1.9 & 5 \\
\hline Weekly & 13.6 & 20 & 14.3 & 20 & 4.8 & 10 & 21.2 & 26.7 & 13.5 & 19.2 \\
\hline Monthly & 31.8 & 5 & 21.4 & 20 & 4.8 & 5 & 9.1 & 20 & 16.8 & 12.5 \\
\hline On tests & 45.5 & 65 & 57.1 & 40 & 85.7 & 65 & 63.6 & 46.7 & 63 & 54.2 \\
\hline Never & 4.5 & 5 & 7.1 & 20 & 4.8 & 5 & 3.1 & 6.7 & 4.9 & 9.2 \\
\hline
\end{tabular}

males. The percentages of those who studied more than five hours are $9.3 \%$ and $33 \%$ for both boys and girls respectively.

The subjects' responses here are in agreements with what already mentioned in the previous item. Male respondents spent less times than females in their study. More girls studied between three to four hours and more girls studied more than five hours each time. These results are in agreement with the observations and with the instructors' reports. It is also in agreement with the findings of research in which statistics indicate that the time spent studying by most students is dramatically below the time expected from students (Nonis et al., 2006). However, the participants' responses in the questionnaire were somewhat exaggerated and this was normal for this type of students who always tried to show themselves in a good face.

Question 3: How many times do you study in a semester?

The data in Table 4 show that students who studied only once a semester recorded $23.8 \%$ and $20 \%$ for males and females respectively. A considerable number of the male students $(34.5 \%)$ and females (29\%) studied twice. Almost the same percentages $(28.4 \%$ and $28.8 \%)$ of both genders studied three times. More females $(28 \%)$, however, studied more than three times compared with males (13.4\%).

Though boys seemed to exaggerate the number of times they studied, yet as a general tendency, they tended to study fewer times than girls did. Again, this is in agreement with our expectations and with our classroom observations. Instructors said that students, particularly boys, studied only for examinations. Though some of the participants said they studied more than three hours, yet we can conclude that they did this only if they had quizzes, tests or examinations.

Question 4: When do you usually read the assigned text?

As shown in Table 5 the big majority of both genders $77.2 \%$ males and $76.7 \%$ females read the assigned text before tests not before classes. Only $2.9 \%$ of males said they read before class. None of the girls studied before class. More females (12.1\%) than males (11.7\%) indicated they studied after class.

As indicated above, most of the subjects said they studied mostly for tests and examinations. This is true of both girls and boys. Though this is against our expectations regarding girls as they proved to perform better than their counterparts, yet they appeared to be more honest as they said they mainly studied for examinations. This is however, does not negate the fact that they outperformed the boys and that they read more and better. Again, there is agreement in all the three tools that students read material mainly to take examinations. As for those who said they read before they came to class, there was no evidence that showed they were doing that. In other words, they were not accurate.

Question 5: Where do you like to study?

Figures in Table 6 show that about two thirds of the males (73.7\%) and more than a half of the females (61.7\%) said they studied in their own rooms. The responses in the given table show that only small numbers of both genders said they either studied in the sitting rooms, or in other places. Only $5 \%$ of the males said they studied at the library. More girls $(12.5 \%)$ studied at the library.

Again we can see here that more girls studied at library. On the other hand, none of the males reported to do the same. This shows that females were more serious. Moreover, more males studied in the sitting rooms where distraction is more inevitable. This shows that boys were not as serious as girls were.

Question 6: Why do you usually study?

This question tried to explore the reasons the respondents gave for studying. Table 7 shows that more than a quarter of the males $(25.3 \%)$ said they studied to please their parents. Fewer girls, however, (11.7\%) opted for this response. About $11 \%$ of the boys studied to do assignments. On the other hand, about $30.4 \%$ females said they studied to do assignments. Less than half of the males (44\%) said they studied to pass the examinations against $1.25 \%$ of the females. Only $14 \%$ of the male students said they studied out of their own desire to understand. Females, on the other hand, recorded more than a half of the responses (51.5\%). Studying for other reasons got almost the same percentages for both genders: $5.1 \%$ against $5.4 \%$ for both boys and girls respectively.

Looking for the reasons the students gave for studying, we found that a quarter of the males studied only to please their parents. This means if it was not to please their parents, they won't study. Moreover, nearly about a half of them studied to do examination. In other words, if it was not to pass the examinations they may not study at all. Most importantly, those males who said they studied out of their own desire to understand made only $14 \%$. This is in agreement with what the instructors observed that students particularly males were careless and demotivated. Females on the other hand, were somewhat better performers. More girls studied out of their own desire and fewer studied to please their parents, or to take examinations. Though girls performed better than boys, yet they can still be classified as not really that 
Table 3. Number of studying hours

\begin{tabular}{|c|c|c|c|c|c|c|c|c|c|c|}
\hline \multirow[t]{3}{*}{ Question No. 2} & \multicolumn{8}{|c|}{ Academic year } & \multicolumn{2}{|c|}{ Total in percentages } \\
\hline & \multicolumn{2}{|c|}{ Year 1} & \multicolumn{2}{|c|}{ Year 2} & \multicolumn{2}{|c|}{ Year 3} & \multicolumn{2}{|c|}{ Year 4} & & \\
\hline & M & $\mathbf{F}$ & $\mathbf{M}$ & $\mathbf{F}$ & $\mathbf{M}$ & $\mathbf{F}$ & $\mathbf{M}$ & $\mathbf{F}$ & M & $\mathbf{F}$ \\
\hline $0-1 \mathrm{hrs}$ & 54.5 & 20 & 21.4 & --- & 14.3 & 5 & 45.5 & 6.7 & 33.9 & 9 \\
\hline $2-3 \mathrm{hrs}$ & 36.4 & 35 & 57.1 & 40 & 47.7 & 10 & 33.3 & 15 & 43.6 & 25 \\
\hline $4-5 \mathrm{hrs}$ & 9.1 & 25 & 14.3 & 40 & 28.6 & 40 & 9.1 & 26.7 & 13.3 & 33 \\
\hline $5+\mathrm{hrs}$ & --- & 20 & 7.1 & 20 & 9.5 & 45 & 21.1 & 46.7 & 9.3 & 33 \\
\hline
\end{tabular}

Table 4. Number of study times

\begin{tabular}{|c|c|c|c|c|c|c|c|c|c|c|}
\hline \multirow[t]{3}{*}{ Question No. 3} & \multicolumn{8}{|c|}{ Academic year } & \multicolumn{2}{|c|}{ Total in percentages } \\
\hline & \multicolumn{2}{|c|}{ Year 1} & \multicolumn{2}{|c|}{ Year 2} & \multicolumn{2}{|c|}{ Year 3} & \multicolumn{2}{|c|}{ Year 4} & & \\
\hline & $\mathbf{M}$ & $\mathbf{F}$ & M & $\mathbf{F}$ & M & $\mathbf{F}$ & M & $\mathbf{F}$ & $\mathbf{M}$ & $\mathbf{F}$ \\
\hline a. Once & 27.3 & 15 & 21.4 & 20 & 19 & 35 & 27.3 & 13.3 & 23.8 & 20.8 \\
\hline b. Twice & 27.3 & 55 & 35.7 & --- & 47.6 & 15 & 27.3 & 46.7 & 34.5 & 29.2 \\
\hline c. 3 times & 36.4 & 20 & 21.4 & 40 & 28.6 & 20 & 27.3 & 33.3 & 28.4 & 28.3 \\
\hline d. $3+$ & 9.1 & 10 & 21.4 & 40 & 4.8 & 30 & 18.2 & 6.7 & 13.4 & 21.7 \\
\hline
\end{tabular}

Table 5. Usual time for reading a text

\begin{tabular}{|c|c|c|c|c|c|c|c|c|c|c|}
\hline \multirow[t]{3}{*}{ Question No. 4} & \multicolumn{8}{|c|}{ Academic year } & \multicolumn{2}{|c|}{ Total in percentages } \\
\hline & \multicolumn{2}{|c|}{ Year 1} & \multicolumn{2}{|c|}{ Year 2} & \multicolumn{2}{|c|}{ Year 3} & \multicolumn{2}{|c|}{ Year 4} & & \\
\hline & M & $\mathbf{F}$ & M & $\mathbf{F}$ & $\mathbf{M}$ & $\mathbf{F}$ & $\mathbf{M}$ & $\mathbf{F}$ & M & $\mathbf{F}$ \\
\hline a. Before tests & 72.7 & 85 & 64.3 & 60 & 90 & 75 & 81.8 & 86.7 & 77.2 & 76.7 \\
\hline b. Before class & --- & --- & 7.1 & --- & 4.8 & --- & --- & --- & 2.9 & --- \\
\hline c. After class & 13.6 & 5 & 14.3 & 20 & 4.8 & 10 & 6.1 & 13.3 & 9.7 & 12.1 \\
\hline d. Other & 13.6 & 10 & 14,3 & 20 & --- & 15 & 21.1 & --- & 11.3 & 11.3 \\
\hline
\end{tabular}

serious. Very few girls said they did not study to take examinations. Instead, they said they studied to do assignments. This is rather a kind of contradiction. Instructors said that girls copies assignments from each other. Therefore, girls seem not to give accurate answers. This is confirmed by the contradictory responses. How did they study for assignments not for examination? Otherwise the contradictory response may indicate that they were not taking the question seriously.

Question 7: Do you take notes during lectures?

Table 8 presents the data for the students' responses about taking notes after instructors. Only $13.9 \%$ of the males said they 'always' took notes. Females, on the other hand recorded 29.2\%, which is higher compared to males. About $25.8 \%$ said 'often', $\%, 44.4$, 'sometimes', and 15.9\%, 'never'. Most of the females $(43.35 \%)$ said they took notes. The number of the girls who said they never took notes was only $7.9 \%$ and this is less than males.

Taking notes is considered one indication that students are serious about their study. If we take the students' responses as accurate, we can see that most of them are not regular in taking notes. Now observations and informal meetings showed that students of both genders generally did not take notes. This is true of both genders, boys in particular. We conclude that at least most of participants did not take notes during lectures.
Question 8: Do you take notes while studying (revising)? This questions investigated if the students took notes while revising their lectures Table 9. The number of the females who always took notes during their studying was $(35.8 \%)$, which was higher compared with males $(18.2 \%)$. Most of the males (41.3\%) said they 'sometimes' took notes. Males who 'never' took notes recorded about $11.1 \%$ whereas fewer girls (8. 3\%) never took notes.

These responses are consistent with what has been observed in the previous section. Students particularly males did not take notes while revising their lectures after class. Less than one fifth of the males said they always took notes and about one tenth never took notes at all. Even here girls still do better according to their given responses. More girls are regular in taking notes and fewer who never take notes at all. Observations and informal meetings with instructors did not give data on this point. But we can conclude that as they did not take notes during classes, it is a possibility that they did not do that during revision.

Question 9: When you take notes, do you review them?

As shown in Table 10, males' responses were as follows: 'always' (24.4\%), 'often' (29.5\%), 'sometimes', (35.9\%) and 'never' $(9.7 \%)$. On the other hand, females' responses were: 'always' (36.7\%), 'often' (30.8\%), 'sometimes',(28.8\%) and 'never' (3.8\%). 
Table 6. Preferred places for studying

\begin{tabular}{|c|c|c|c|c|c|c|c|c|c|c|}
\hline \multirow[t]{3}{*}{ Question No. 5} & \multicolumn{8}{|c|}{ Academic year } & \multicolumn{2}{|c|}{ Total in percentages } \\
\hline & \multicolumn{2}{|c|}{ Year 1} & \multicolumn{2}{|c|}{ Year 2} & \multicolumn{2}{|c|}{ Year 3} & \multicolumn{2}{|c|}{ Year 4} & & \\
\hline & M & $\mathbf{F}$ & M & $\mathbf{F}$ & $\mathbf{M}$ & $\mathbf{F}$ & $\mathbf{M}$ & $\mathbf{F}$ & M & $\mathbf{F}$ \\
\hline a. My room & 54.5 & 80 & 85.7 & 40 & 76.2 & 60 & 75.8 & 66.7 & 73.1 & 61.7 \\
\hline b.Ssitting room & 22.7 & 10 & 7.1 & 20 & 9.5 & 20 & 12.1 & 26.8 & 12.9 & 19.2 \\
\hline c. At library & 9.1 & --- & --- & 40 & 9.5 & 10 & 3 & --- & 5.4 & 12.5 \\
\hline d. Other & 13.6 & 10 & 7.1 & --- & 4.8 & 10 & 9.1 & 6.7 & 8.7 & 6.7 \\
\hline
\end{tabular}

Table 7. Reasons for studying

\begin{tabular}{|c|c|c|c|c|c|c|c|c|c|c|}
\hline \multirow[t]{3}{*}{ Question No 6} & \multicolumn{8}{|c|}{ Academic year } & \multicolumn{2}{|c|}{ Total in percentages } \\
\hline & \multicolumn{2}{|c|}{ Year 1} & \multicolumn{2}{|c|}{ Year 2} & \multicolumn{2}{|c|}{ Year 3} & \multicolumn{2}{|c|}{ Year 4} & & \\
\hline & $\mathbf{M}$ & $\mathbf{F}$ & $\mathbf{M}$ & $\mathbf{F}$ & $\mathbf{M}$ & $\mathbf{F}$ & $\mathbf{M}$ & $\mathbf{F}$ & $\mathbf{M}$ & $\mathbf{F}$ \\
\hline a. Please parents & 40.9 & 10 & 21.4 & 20 & 23.8 & 10 & 15.2 & 6.7 & 25.3 & 11.7 \\
\hline b. Do assignments & 13.6 & 30 & --- & 40 & --- & 25 & 30.3 & 26.7 & 11 & 30.4 \\
\hline c. To take exams & 31.8 & 5 & 42.9 & --- & 61.9 & --- & 39.4 & --- & 44 & 1.25 \\
\hline d. My desire & 13.6 & 45 & 21.4 & 40 & 14.3 & 60 & 6.1 & 60 & 14 & 51.5 \\
\hline e. Other & --- & 10 & 14.3 & --- & --- & 05 & 9.1 & 6.7 & 5.1 & 5.4 \\
\hline
\end{tabular}

Table 8. Taking notes during lectures

\begin{tabular}{|c|c|c|c|c|c|c|c|c|c|c|}
\hline \multirow[t]{3}{*}{ Question No. 7} & \multicolumn{8}{|c|}{ Academic year } & \multicolumn{2}{|c|}{ Total in percentages } \\
\hline & \multicolumn{2}{|c|}{ Year 1} & \multicolumn{2}{|c|}{ Year 2} & \multicolumn{2}{|c|}{ Year 3} & \multicolumn{2}{|c|}{ Year 4} & & \\
\hline & $\mathbf{M}$ & $\mathbf{F}$ & M & $\mathbf{F}$ & M & $\mathbf{F}$ & $\mathbf{M}$ & $\mathbf{F}$ & $\mathbf{M}$ & $\mathbf{F}$ \\
\hline a. Always & 9.1 & 20 & 14.3 & 40 & 14.3 & 30 & 18.2 & 26.7 & 13.9 & 29.2 \\
\hline b. Often & 18.2 & 15 & 21.4 & 20 & 33.3 & 30 & 30.3 & 13.3 & 25.8 & 19.6 \\
\hline c. Sometimes & 40.9 & 50 & 57.1 & 40 & 42.8 & 30 & 36.4 & 53.3 & 44.3 & 43.3 \\
\hline d. Never & 31.8 & 15 & 7.1 & --- & 9.5 & 10 & 15.2 & 6.7 & 15.9 & 7.9 \\
\hline
\end{tabular}

Table 9. Taking notes while revising

\begin{tabular}{|c|c|c|c|c|c|c|c|c|c|c|}
\hline \multirow[t]{3}{*}{ Question No: 8} & \multicolumn{8}{|c|}{ Academic year } & \multicolumn{2}{|c|}{ Total in percentage } \\
\hline & \multicolumn{2}{|c|}{ Year 1} & \multicolumn{2}{|c|}{ Year 2} & \multicolumn{2}{|c|}{ Year 3} & \multicolumn{2}{|c|}{ Year 4} & & \\
\hline & $\mathbf{M}$ & $\mathbf{F}$ & M & $\mathbf{F}$ & M & $\mathbf{F}$ & M & $\mathbf{F}$ & M & $\mathbf{F}$ \\
\hline a. Always & 4.5 & 40 & 14.3 & 40 & 23.8 & 30 & 30.3 & 33.3 & 18.2 & 35.8 \\
\hline b. Often & 36.4 & 30 & 28.6 & 40 & 28.6 & 15 & 24.2 & 13.3 & 29.5 & 24.6 \\
\hline c. Sometimes & 50 & 25 & 50 & 20 & 28.6 & 45 & 36.4 & 33.3 & 41.3 & 30.8 \\
\hline d. Never & 9.1 & 05 & 7.1 & --- & 19 & 10 & 9.1 & 20 & 11.1 & 8.3 \\
\hline
\end{tabular}

Table 10. Reviewing one's notes

\begin{tabular}{|c|c|c|c|c|c|c|c|c|c|c|}
\hline \multirow[t]{3}{*}{ Question No.9 } & \multicolumn{8}{|c|}{ Academic year } & \multicolumn{2}{|c|}{ Totals in percentages } \\
\hline & \multicolumn{2}{|c|}{ Year 1} & \multicolumn{2}{|c|}{ Year 2} & \multicolumn{2}{|c|}{ Year 3} & \multicolumn{2}{|c|}{ Year 4} & & \\
\hline & M & $\mathbf{F}$ & M & $\mathbf{F}$ & M & $\mathbf{F}$ & M & $\mathbf{F}$ & M & $\mathbf{F}$ \\
\hline a. Always & 4.6 & 40 & 28.6 & 20 & 33.3 & 40 & 33.3 & 46.7 & 24.4 & 36.7 \\
\hline b. Often & 31.8 & 30 & 35.7 & 60 & 14.3 & 20 & 36.4 & 13.3 & 29.5 & 30.8 \\
\hline c. Sometimes & 45.5 & 25 & 21.4 & 20 & 52.4 & 30 & 24.2 & 40 & 35.9 & 28.8 \\
\hline d. Never & 18.2 & 05 & 14.3 & --- & --- & 10 & 6.1 & --- & 9.7 & 3.8 \\
\hline
\end{tabular}


We have seen earlier that the majority of the participants neither took notes in class nor at home while reviewing. If we take what the participants said for granted (see Table 9) then those who took notes, and those who revised them, represented a small minority and at the same time they are irregular in reviewing their notes.

Question 10: Do you make yourself a schedule for revising?

The data in Table 11 indicate that about $(36.4 \%)$ of the females said they 'always' planned their study time. Unlike females, only $17.4 \%$ males were found to always schedule their study. Males who did not plan their study time made about $36.4 \%$ against $26.7 \%$ of the females.

As always the case, males performed worse than females in planning their study time. If we only consider those who said they 'never' plan studied time of both genders, we can see that almost one third of the participants came under this category. If we add to this those who said they 'sometimes' did it, this will be majority of the boys $(65.5 \%)$ and the girls $(46.7 \%)$ we can confidently say that the majority of the participants studied randomly and did not follow any schedules. This is of course if we take what they said for granted. If we, however, take into account that the students usually tend to exaggerate their responses and give inaccurate answers then the situation will be worse. Girls,of course still perform better than their counterparts.
Question 11: When do you study better?

The data presented in Table 12 tell us that most of the students of both genders said that they studied better when studying alone making $47.1 \%$ of boys compared with $63.3 \%$ of girls. Those who preferred studying with a partner recorded $33.8 \%$ males and $27.5 \%$ females. Studying with groups came next with $17.3 \% \%$ against $9.2 \%$ females.

It is normal to find a majority of students studied alone and not in groups or with partners. This can be an advantage and a disadvantage at the same time. It is an advantage because studying in groups means wasting time in useless matters like chatting. It is a disadvantage because studying in groups means students make use of critical thinking skills like discussing, analyzing, evaluating, commenting reflecting, adding and enriching ideas. But as our everyday observations indicate, we can see that students do not make a good use of group studying.

Question 12: When you do not understand, do you ask your instructor?

Whether or not the students asked their instructors when they did not understand, the responses given in Table 13 are as follows: 'always' $9.2 \%$ for males against $11.3 \%$ for females, 'often' $19.7 \%$ for males against $11.3 \%$ for females; 'sometimes' $55.1 \%$ for males against $54.6 \%$ for females; and 'never; $16.1 \%$ and $22.9 \%$ for males and females respectively.

Table 11. Planning study time

\begin{tabular}{|c|c|c|c|c|c|c|c|c|c|c|}
\hline \multirow[t]{3}{*}{ Question No. 10} & \multicolumn{8}{|c|}{ Academic year } & \multicolumn{2}{|c|}{ Total in percentages } \\
\hline & \multicolumn{2}{|c|}{ Year 1} & \multicolumn{2}{|c|}{ Year 2} & \multicolumn{2}{|c|}{ Year 3} & \multicolumn{2}{|c|}{ Year 4} & & \\
\hline & M & $\mathbf{F}$ & $\mathbf{M}$ & $\mathbf{F}$ & $\mathbf{M}$ & $\mathbf{F}$ & $\mathbf{M}$ & $\mathbf{F}$ & $\mathbf{M}$ & $\mathbf{F}$ \\
\hline a. Always & 13.6 & 15 & 14.3 & 40 & 14.3 & 50 & 27.3 & 33.3 & 17.4 & 34.6 \\
\hline b. Often & 13.6 & 25 & 28.6 & 20 & 14.3 & 10 & 12.1 & 20 & 17.2 & 18.8 \\
\hline c. Sometimes & 31.8 & 30 & 21.4 & --- & 23.8 & 30 & 39.4 & 20 & 29.1 & 20 \\
\hline d. Never & 40.9 & 30 & 35.7 & 40 & 47.6 & 10 & 21.2 & 26.7 & 36.4 & 26.7 \\
\hline
\end{tabular}

Table 12. When studying better

\begin{tabular}{|c|c|c|c|c|c|c|c|c|c|c|}
\hline \multirow[t]{3}{*}{ Question No. 11} & \multicolumn{8}{|c|}{ Academic year } & \multicolumn{2}{|c|}{ Total in percentages } \\
\hline & \multicolumn{2}{|c|}{ Year 1} & \multicolumn{2}{|c|}{ Year 2} & \multicolumn{2}{|c|}{ Year 3} & \multicolumn{2}{|c|}{ Year 4} & & \\
\hline & M & $\mathbf{F}$ & M & $\mathbf{F}$ & M & $\mathbf{F}$ & $\mathbf{M}$ & $\mathbf{F}$ & M & $\mathbf{F}$ \\
\hline a. Alone & 40.9 & 70 & 50 & 80 & 42.9 & 50 & 54.5 & 53.3 & 47.1 & 63.3 \\
\hline b. With partner & 36.4 & 30 & 42.9 & 20 & 28.6 & 40 & 27.3 & 20 & 33.8 & 27.5 \\
\hline c. With groups & 18.2 & --- & 7.1 & --- & 28.6 & 10 & 15.2 & 26.7 & 17.3 & 9.2 \\
\hline d. Not applied & 4.5 & --- & --- & --- & --- & --- & 3 & --- & 1.9 & --- \\
\hline
\end{tabular}

Table 13. Asking the instructor

\begin{tabular}{|c|c|c|c|c|c|c|c|c|c|c|}
\hline \multirow[t]{3}{*}{ Question No. 12} & \multicolumn{8}{|c|}{ Academic year } & \multicolumn{2}{|c|}{ Total in percentages } \\
\hline & \multicolumn{2}{|c|}{ Year 1} & \multicolumn{2}{|c|}{ Year 2} & \multicolumn{2}{|c|}{ Year 3} & \multicolumn{2}{|c|}{ Year 4} & & \\
\hline & M & $\mathbf{F}$ & M & $\mathbf{F}$ & $\mathbf{M}$ & $\mathbf{F}$ & M & $\mathbf{F}$ & $\mathbf{M}$ & $\mathbf{F}$ \\
\hline a. Always & 22.7 & 20 & --- & 20 & 4.8 & 5 & 9.1 & --- & 9.2 & 11.3 \\
\hline b. Often & 18.2 & 10 & 21.4 & 20 & 23.8 & 15 & 15.2 & --- & 19.7 & 11.3 \\
\hline c. Sometimes & 40.9 & 55 & 57.1 & 20 & 61.9 & 50 & 60.6 & 93.3 & 55.1 & 54.6 \\
\hline d. Never & 18.2 & 15 & 21.4 & 40 & 9.5 & 30 & 15.2 & 6.7 & 16.1 & 22.9 \\
\hline
\end{tabular}


More than a half of each group said they only 'sometimes' asked their instructors for clarification or to understand. If we add to this those who 'never' asked we can conclude that most of the respondents did not ask their instructors regularly. Observations and meetings with instructors indicated that students were almost always passive _ boys in particular. Girls' instructors said that though girls were considered passive, yet they asked more frequently than boys did. As for my observations, I can say I won't be exaggerating if I say that $99 \%$ of the students do not ask even if they do not understand the content.

Question 13: Do you switch off your mobile during your study?

As can be seen in Table 14 the percentages of those who 'always' switched of their mobiles were $16.7 \%$ and $18.6 \%$ for both males and females respectively. On the other hand, those who never switched off theirs made $26.6 \%$ and $21.3 \%$ for both boys and girls respectively. The remaining percentages were distributed between 'often' and 'sometimes'.

As the figures show, about a quarter of each group of the participants said they did not switch off their mobiles during study or revision. If we add to this percentage those who 'sometimes' switch off their mobiles, we can say the majorities in both groups studied while their mobile were on, which means the students did not pay real attention to their study and kept engaged in things other than studying.

Question 14: Do you test yourself after studying?

Results in Table 15 show that most of the students of both genders said they tested themselves after each time they studied or revised. Only a small proportion of about only $8.2 \%$ boys and $10.8 \%$ girls said they 'never' tested themselves. Of course not all of those who said they tested themselves were at the same rate. Some did it regularly some did not. Whether what the students said was true or not is left to the their honesty. We teachers doubt this as the students' performance does not reflect this.

\section{CONCLUSIONS}

From the results and results discussion presented above the following points can be concluded:

1. The participants did not study outside the classroom. When they did, they did that mainly to please their parents, take tests and examinations or do graded tasks.

2. The studied groups were irregular, frequently came late to classroom, and usually were reluctant to have classes. Because they stayed up late, some of them fell asleep in classroom and therefore were inattentive to what their instructors said.

3. Most of the subjects did not bring note books, or pens. to classrooms. Few students cared to take notes in classroom or during studying at home. Those who took notes rarely made use of them.

4. Both genders were generally inactive in the classroom; they did not participate in asking questions even when they did not understand the content. They rarely answered questions, added new ideas, tried to be reflective or creative.

5. Most of them preferred to study alone. However, many of them did not switch off their cell mobiles while revising or studying.

6. Due to all this, performance is poor and achievement is very low. The main goal for them was to pass the exam. To achieve this goal, the participants resorted to cheating, plagiarizing, copying from each other's assignments letting others do assignments for them.

7. The majority of the subjects did not follow schedules for revising their lectures. In other words, they revised randomly and unsystematically.

8. When given tasks or assignments, they either did not do them, or they did not hand them over to instructors on time.

Table 14. Switching off the mobile phone

\begin{tabular}{|c|c|c|c|c|c|c|c|c|c|c|}
\hline \multirow[t]{3}{*}{ Question No. 13} & \multicolumn{8}{|c|}{ Academic year } & \multicolumn{2}{|c|}{ Total in percentages } \\
\hline & \multicolumn{2}{|c|}{ Year 1} & \multicolumn{2}{|c|}{ Year 2} & \multicolumn{2}{|c|}{ Year 3} & \multicolumn{2}{|c|}{ Year 4} & & \\
\hline & M & $\mathbf{F}$ & $\mathbf{M}$ & $\mathbf{F}$ & $\mathbf{M}$ & $\mathbf{F}$ & M & $\mathbf{F}$ & M & $\mathbf{F}$ \\
\hline a. Always & 4.5 & 25 & 35.7 & --- & 14.3 & 30 & 12.1 & 20 & 16.7 & 18.6 \\
\hline b. Often & 50 & 20 & 14.3 & 60 & 14.3 & 10 & --- & 20 & 19.7 & 27.5 \\
\hline c. Sometimes & 18.2 & 20 & 35.7 & 20 & 52.4 & 50 & 42.4 & 40 & 37.2 & 32.5 \\
\hline d. Never & 27.3 & 35 & 14.7 & 20 & 19 & 10 & 45.5 & 20 & 26.6 & 21.3 \\
\hline
\end{tabular}

Table 15. Testing oneself

\begin{tabular}{|c|c|c|c|c|c|c|c|c|c|c|}
\hline \multirow[t]{3}{*}{ Question No. 14} & \multicolumn{8}{|c|}{ Academic year } & \multicolumn{2}{|c|}{ Total in percentages } \\
\hline & \multicolumn{2}{|c|}{ Year 1} & \multicolumn{2}{|c|}{ Year 2} & \multicolumn{2}{|c|}{ Year 3} & \multicolumn{2}{|c|}{ Year 4} & & \\
\hline & $\mathbf{M}$ & $\mathbf{F}$ & $\mathbf{M}$ & $\mathbf{F}$ & $\mathbf{M}$ & $\mathbf{F}$ & $\mathbf{M}$ & $\mathbf{F}$ & $\mathbf{M}$ & $\mathbf{F}$ \\
\hline a. Aalways & 45.5 & 45 & 14.3 & 60 & 57.1 & 40 & 39.4 & 40 & 39.1 & 46.3 \\
\hline b. Often & 27.3 & 20 & 42.9 & 40 & 14.3 & 15 & 18.2 & 6.7 & 25.7 & 20.4 \\
\hline c. Sometimes & 13.6 & 25 & 28.6 & --- & 23.8 & 25 & 42.4 & 40 & 27.1 & 22.5 \\
\hline d. Never & 13.6 & 10 & 14.3 & --- & 4.8 & 20 & --- & 13.3 & 8.2 & 10.8 \\
\hline
\end{tabular}


9. Females' study habits were generally found to be comparatively better than those of the males; more girls spent more time in studying; they studied more than once; they studied out of their own desire rather than to please parents or do examinations, and they took notes and revised these notes more frequently than males did. Instructors ascertained this differences. This situation is also supported by writers like Carroll, Horwood, Burstall et al (as cited in Yazigy,1991), who found that females did better than males. However, the reasons for this difference were not obvious.

10. Generally, we can say that students of English study habits were poor. The main cause for this situation as agreed upon among instructors was lack of motivation to learn. The causes of this demotivation, in turn, can be attributed to different social, economic factors.

11. Observations and meetings with instructors showed that participants generally were underachievers. This underachievement was reflected in the poor study habits and the vice versa. Therefore, negative relationship was found between students' study habits and their academic performance. Bad study habits resulted in the poor performance.

\section{RECOMMENDATIONS}

1. All stock holders in the educational process weather policy makers educators, course designers, and instructors should look at the role of study habits in the students' performance and undertake appropriate corrective measures.

2. Parents should be seriously involved the education process of their children. They should follow up their children and direct them to the right study habits. They should trace the different study habits of their children and see the amount of time devoted to study, consider if their children are committed to study, if they study seriously and when, how, where and with whom they study and so on.

3. The state of demotivation of the students should be examined and the causes behind it should be explored.

4. Teachers should keep guiding, reminding and recommending their students of the good study habits they have to follow and direct them to the qualities of the good English student.

\section{SUGGESTIONS}

1. A further and more extended studies on the relationship between study habits and performance of the students of English in particular, should be carried out to include more colleges and universities at different regions in the kingdom.

2. Studies should be conducted to find out the causes behind the EFL students.

\section{REFERENCES}

Al Murshidi, G. (2014). UAE university male students' interests impact on reading and writing performance and improvement. English Language Teaching, 7(9), 57.

Andrade, M. S. (2006). International students in English-speaking universities: Adjustment factors. Journal of Research in International education, 5(2), 131-154.

Atieh, S. H. (1997). Student perceptions of the causes of low performance in principles of accounting: A case study in Saudi Arabia. Journal of King Fahd University: Economics \& Administration, 10, 35-50.

Benford, R. \& Gess-Newsome, J.(2006). Factors affecting student academic success in gateway courses at Northern Arizona University. Center for Science Teaching and Learning. Northern Arizona University Flagstaff, AZ 86011-5697.Omline submission.

Cerna, M. A., \& Pavliushchenko, K. (2015). Influence of study habits on academic performance of international college students in Shanghai. Higher Education Studies, 5(4), 42.

Chan, D., Schmitt, N., Sacco, J. M., \& DeShon, R. P. (1998). Understanding pretest and posttest reactions to cognitive ability and personality tests. Journal of Applied Psychology, 83(3), 471.

Coffield, F., Moseley, D., Hall, E., \& Ecclestone, K. (2004). Learning styles and pedagogy in post-16 learning: A systematic and critical review.

Credé, M., \& Kuncel, N. R. (2008). Study habits, skills, and attitudes: The third pillar supporting collegiate academic performance. Perspectives on Psychological Science, 3(6), 425-453.

Chokri Inoubli, (2013) Relationship between students' study habits and academic achievement: A cCase study of Najran University scientific papers, Najran University. Available at https://www.nu.edu.sa /.../

Entwistle, N., \& McCune, V. (2004). The conceptual bases of study strategy inventories. Educational Psychology Review, 16(4), 325-345.

Franklin, (2017). Learn more effectively with these 5 study habits. Franklin University/www.franklin.edu.

Gurung, R. A., \& McCann, L. I. (2011). How should students study? Tips, advice, and pitfalls. APS Observer, 24(4), 33-35.

Gurung, R. A., \& Schwartz, B. M. (2011). Optimizing teaching and learning: Practicing pedagogical research. John Wiley \& Sons.

Gurung, R. A., Weidert, J., \& Jeske, A. (2010). Focusing on how students study. Journal of the Scholarship of Teaching and Learning, 10(1), 28-35.

Hattie, J. A. (2009). Visible learning: A synthesis of $800+$ meta-analyses on achievement. Abingdon: Routledge.

Justicia, F. (1994). Learning strategies, styles and approaches: an analysis of their interrelationships. Higher Education, 27(2), 239-260.

Khan, I. A. (2011). Diagnosis of learning difficulties in English: The Arabic bilingual context. Elixir Psychology, 36, 3448-3454.

Krohn, G. A., \& O’Conner, C. M. (2005). Student effort and performance over semester. Journal of Economic Education, 36, 3-29

Mohammad, T., \& Hazarika, Z. (2016). Difficulties of learning EFL in KSA: Writing skills in context. International 
Journal of English Linguistics, 6(3), 105.

Neal, D. T., Wood, W., \& Quinn, J. M. (2006). Habits-A repeat performance. Current Directions in Psychological Science, 15(4), 198-202.

Nonis, S. A., \& Hudson, G. I. (2010). Performance of college students: Impact of study time and study habits. Journal of Education for Business, 85(4), 229-238.

Nonis, S. A., Philhours, M. J., \& Hudson, G. I. (2006). Where does the time go? A diary approach to business and marketing students' time use. Journal of Marketing Education, 28(2), 121-134.

Nonis, S. A., \& Hudson, G. I. (2006). Academic performance of college students: Influence of time spent studying and working. Journal of Education for Business, 81(3), 151-159.

Lawson, L. A. (2009). The Learning and Study Strategies Inventory as a predictive measure of $1^{\text {st }}$ semester academic performance of at-risk students(Doctoral dissertation, Florida State University). Retrieved from http:// www.diginole.lib.fsu.edu/cgi/viewcontent.cgi?article $=2875 \&$ context $=$ etd

Oxford, R. L., \& Burry-Stock, J. A. (1995). Assessing the use of language learning strategies worldwide with the ESL/EFL version of the Strategy Inventory for Language Learning (SILL). System, 23(1), 1-23.

Schuman, H., Walsh, E., Olson, C., \& Etheridge, B. (1985). Effort and reward: The assumption that college grades are affected by quantity of study. Social Forces, 63(4), 945-966.

Simons, J., Dewitte, S., \& Lens, W. (2004). The role of different types of instrumentality in motivation, study strategies, and performance: Know why you learn, so you'll know what you learn!. British Journal of Educational Psychology, 74(3), 343-360.

Springsteen, S. M. (2014). Examining student motivation in Saudi Arabia. Available at: http://works.bepress.com/ sarah_springsteen/2

Thiyagu, K.(2013). Study habits and academic achievement of ninth standard students. IJPE Journal. Available at http://www.academia.edu/download/34268236/THIYAGU - ARTICLE 5.pdf.

West, C., \& Sadoski, M. (2011). Do study strategies predict academic performance in medical school?. Medical education, 45(7), 696-703.

Yazigy, R. J. (1991). Social and psychological factors in learning English as a foreign language in Lebanon. Thesis submitted for the degree of doctor of philosophy in applied linguistics at the School of Education University of Leicester.

Young, M. R., Klemz, B. R., \& Murphy, J. W. (2003). Enhancing learning outcomes: The effects of instructional technology, learning styles, instructional methods, and student behavior. Journal of Marketing Education, 25(2), 130-142. 